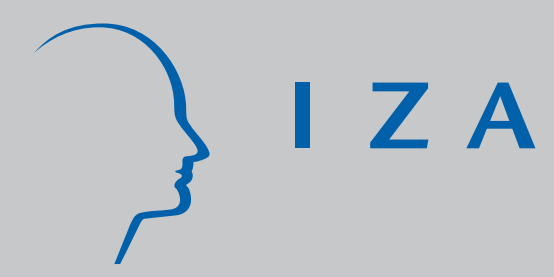

IZA DP No. 1742

The Impact of Gender Segregation on Male-Female Wage Differentials: Evidence from Matched

Employer-Employee Data for Spain

Catalina Amuedo-Dorantes

Sara de la Rica

September 2005 


\title{
The Impact of Gender Segregation on Male-Female Wage Differentials: Evidence from Matched Employer-Employee Data for Spain
}

\author{
Catalina Amuedo-Dorantes \\ San Diego State University \\ and IZA Bonn \\ Sara de la Rica \\ Universidad del País Vasco \\ and IZA Bonn
}

Discussion Paper No. 1742
September 2005

IZA

P.O. Box 7240

53072 Bonn

Germany

Phone: +49-228-3894-0

Fax: +49-228-3894-180

Email: iza@iza.org

Any opinions expressed here are those of the author(s) and not those of the institute. Research disseminated by IZA may include views on policy, but the institute itself takes no institutional policy positions.

The Institute for the Study of Labor (IZA) in Bonn is a local and virtual international research center and a place of communication between science, politics and business. IZA is an independent nonprofit company supported by Deutsche Post World Net. The center is associated with the University of Bonn and offers a stimulating research environment through its research networks, research support, and visitors and doctoral programs. IZA engages in (i) original and internationally competitive research in all fields of labor economics, (ii) development of policy concepts, and (iii) dissemination of research results and concepts to the interested public.

IZA Discussion Papers often represent preliminary work and are circulated to encourage discussion. Citation of such a paper should account for its provisional character. A revised version may be available directly from the author. 
IZA Discussion Paper No. 1742

September 2005

\section{ABSTRACT}

\section{The Impact of Gender Segregation on Male-Female Wage Differentials: Evidence from Matched Employer-Employee Data for Spain*}

This paper presents new evidence on the role of gender segregation within industry, occupation, establishment, and occupation-establishment cells in explaining gender wage differentials of full-time salaried workers in Spain during 1995 and 2002. Using data from the Spanish Wage Structure Surveys, we find that the raw gender wage gap decreased from 0.26 to 0.22 over the course of seven years. However, even after accounting for workers' human capital, job characteristics, and female segregation into lower-paying industries, occupations, establishments, and occupations within establishments, women still earned approximately 13 percent and 16 percent less than similar male counterparts as of 1995 and 2002, respectively. Most of the gender wage gap is attributable to workers' sex. Yet, female segregation into lower-paying occupations within establishments, establishments and industries accounted for a sizable and growing fraction of the female-male wage differential.

JEL Classification: J16, J7

Keywords: gender wage differentials, female segregation, matched employer-employee data

Corresponding author:

Sara de la Rica

Universidad del País Vasco

Avenida Lehendakari Aguirre, 83

48015 Bilbao

Spain

Email: sara.delarica@ehu.es

\footnotetext{
* We wish to thank David Card, Ronald Oaxaca, and seminar participants at the University of Tucson and at the University of Berkeley for helpful comments. We also appreciate helpful comments from Florentino Felgueroso on earlier drafts of the paper. Financial help from the Spanish Ministry of Science (SEC2003-04826) is gratefully acknowledged.
} 


\section{Introduction}

Gender wage gaps continue to characterize modern labor markets despite their reduction over the past two decades in most industrialized countries (e.g. Altonji and Blank 1999, Gosling and Lemieux 2001). While some of the wage gap between men and women is attributable to human capital differences, most of the wage gap is explained by gender segregation into different types of jobs. In this vein, a variety of studies have shown women's concentration into lower-paying occupations (Johnson and Solon 1986, Groshen 1991, MacPherson and Hirsch 1995). Likewise, some authors have found evidence of female segregation into lower-paying establishments (Carrington and Troske 1998). Finally, Meyersson-Milgrom et al. (2001), Bayard et al. (2003), and more recently Gupta and Rothstein (2005) provide evidence of the importance of gender segregation at the occupation-establishment cell level in explaining existing gender wage gaps. Yet, as recently noted by Gupta and Rothstein (2005), less than a handful of studies have examined the role of gender segregation at multiple work levels in explaining persistent gender wage gaps due to the lack of representative datasets including detailed information on workers, establishments, and job characteristics. ${ }^{1}$

This paper adds to the existing literature on gender wage gaps with an analysis of the role of female segregation into lower-paying industries, occupations, establishments, and occupations within establishments in explaining the gender wage gap in Spain using a large matched employer-employee dataset from the mid 1990 s and early $21^{\text {st }}$ century. The analysis of the gender wage gap and the fraction of the female-male wage gap due to gender segregation over

\footnotetext{
${ }^{1}$ Abowd and Kramarz (1999), among others, also point out the importance of the use of matched employeeemployer datasets in labor economics. Yet, such datasets are scarce and often non-representative of the populations
} 
these two time periods is helpful in informing the design of policies that effectively target such differentials. Furthermore, Spain represents an interesting case study for a couple of reasons. First, the literature on the impact of different levels of gender segregation on the female-male wage gap has primarily focused on the U.S. or Northern European countries, such as Denmark, Norway, and Sweden. Yet, there are noticeable differences between Northern European countries, often characterized by low unemployment rates and high female labor force participation rates, and Southern European countries, which often display opposite features. These differences may not be trivial when explaining gender occupational segregation, which also differs substantially across countries. ${ }^{2}$ As such, Spain constitutes an interesting case to study and compare to Northern European nations and to the U.S. Second, in addition to distinct labor market trends, pay structures have been shown to play a quantitatively large role in explaining gender wage gaps (Blau and Kahn 2001). Specifically, countries with wage setting mechanisms based on collective bargaining agreements are likely to display smaller gender wage gaps as collective bargaining raises the relative pay of women often at the bottom of the wage distribution. Therefore, a comparison of the role of gender segregation in explaining femalemale wage gaps in Spain relative to countries with either more individualized wage-setting mechanisms (e.g. the U.K. or the U.S.) or more centralized wage-setting mechanisms (e.g. Nordic economies studied by the literature on gender wage gaps) may hint on the role played by institutional factors in explaining gender wage differentials.

We use data from the 1995 and 2002 Spanish Wage Structure Surveys - known by their acronyms: EES-95 and EES-02. ${ }^{3}$ These two datasets survey establishments in the

\footnotetext{
of interest.

${ }^{2}$ In this regard, Dolado et al. (2004) document the lower occupational segregation characterizing some of the Southern European countries.

${ }^{3}$ Wage surveys similar to the EES 95 are also available in other EC countries, including France, Denmark, Germany,
} 
manufacturing, construction and service industries. Along with information on the establishment, detailed data on wages, education, job tenure and occupation are collected from a random sample of workers in each establishment. We estimate various log hourly wage regressions specifications using: (1) controls for the proportion of females in the industry, occupation, establishment, and occupation-establishment cell levels; (2) occupationestablishment cell level fixed-effects; and (3) augmented pooled OLS regressions including coworker average characteristics to address measurement errors in workers' human capital. In this manner, we are able to gauge the role of female segregation into lower-paying industries, occupations, establishments, and occupations within a establishment in explaining female-male wage differentials. In particular, if we assume that men and women working in the same establishment and in the same occupation do the same job, we can assess the extent to which there is "equal pay for equal work" gender wise as discussed in the "comparable worth" literature (e.g. Johnson and Solon 1986). Additionally, we are able to differentiate between the fraction of the male-female wage differential attributable to gender differences in human capital and the fraction of the gender wage gap due to female segregation into lower-paying industries, occupations, establishments, and occupations within a establishment.

Our results indicate that over the course of seven years, the raw gender wage gap decreased from 0.26 to 0.22 . However, after accounting for workers' human capital, job characteristics, and female segregation into lower-paying industries, occupations, establishments, and occupation-establishment cells, women earned approximately 13 percent and 16 percent less than similar male counterparts as of 1995 and 2002, respectively. Most of the gender wage gap is attributable to workers' sex. Yet, female segregation into lower-paying jobs, establishments and, finally, industries, accounts for a sizable and growing fraction of the female-male wage 
differential.

The rest of the paper is organized as follows. Section 2 reviews the most relevant institutional aspects of the Spanish labor market, whereas section 3 describes the data employed in the empirical analysis. The methodology is explained in section 4 and results are presented and discussed in section 5. Section 6 concludes the study with a summary of our findings and allusions to policy implications.

\section{Institutional Background}

\subsection{Women in the Spanish Labor Market}

Before examining gender segregation and its role in explaining the female-male wage gap in Spain, some relevant characteristics of the Spanish labor market are worth discussing. Perhaps one of the most important features of Southern European economies relative to the U.S. and Northern European nations is the lower rates of female labor force participation (e.g. Ariza et al 2005). As of 2001, the average female labor force participation rate in Spain was 65 percent relative to 81 percent in Denmark, 83 percent in Sweden and 75 percent in the U.K. While the male-female employment rate gap has significantly decreased over time, Spain is still characterized by one of the largest gender employment rate differentials. In this regard, Dolado et al. (2004) report that, as of 1990, the male-female employment rate gap was 16.7 percent in the U.S., about 4.2 percent in Sweden, and 39.4 percent in Spain. This gap was also large in other Southern European nations, e.g. thirty-three percent in Italy and 36 percent in Greece. By 1999, the male-female employment gap had decreased to 31.7 percent in Spain, in part as a result of the higher educational attainment of women and their reduced fertility rates (Arellano and Bover 1995). However, Spanish women still display significantly lower labor force participation rates than women in Northern European OECD countries. 
How strong is occupational segregation among working men and women? Relative to the U.S., Spain exhibits relatively low segregation indexes. Dolado et al. (2004) point out that this is particularly the case for highly educated workers, for whom these indexes are 36 percent in the U.S. relative to 29 percent in Spain. Nonetheless, the indexes are rather similar for low educated workers in both countries ( 49 percent in the U.S. versus 50 percent in Spain). These figures compare to segregation indexes in the order of 16 percent for highly educated workers and 40 percent for low educated workers in Denmark (Dolado et al. 2004).

Finally, how do Spanish women fare relative to men in terms of wages? Plasman and Sissoko (2004, Table 1) compute gender wage gaps for a variety of European countries. As of 1995, the average male-female wage gap was 0.18 in Denmark and 0.28 in Spain; in both instances smaller than the 0.33 gender wage gap reported by Bayard et al. (2003) for the U.S. as of 1990.

\subsection{Wage Setting in Spain}

The 1978 Constitution legalized trade unions and wages, along with other working conditions, became the object of collective bargaining. There are different levels of collective bargaining in Spain: (1) nationwide industry level, (2) regional industry level, and (3) firm level. Due to the existence of multiple levels of collective bargaining, several agreements may simultaneously apply to a group of workers. For instance, working conditions for workers in the metal industry are negotiated by union representatives and employers of the metal industry at the national level. However, in some areas of the country, regional union representatives may gather with employers and agree upon additional working conditions stipulated in an agreement that exclusively pertains to workers in the metal industry in that region. This is known as a regional industry level agreement. Finally, in some typically large firms, worker representatives and 
employers may further negotiate working conditions in firm level agreements that are only applicable to firm employees. In such instances, agreements broader in scope, as is the case with nationwide agreements, serve as a benchmark to agreements with a narrower scope, as is the case with firm level agreements. To serve as reference of the coverage of each level agreement, around 25 percent of workers have their working conditions governed by nationwide industry agreements, fifty-five percent of workers are covered by regional industry agreements and, for approximately 15 percent of workers, various aspects of the work relationship are negotiated at the firm level (for more details, see Card and De la Rica, 2005).

Spanish wages have two distinct components: the base wage and the wage complements for productivity, tenure, or work shift. On average, the base wage accounts for about 65 percent of the entire wage. Each collective bargaining agreement specifies the base wage levels and increments for each of the job categories covered by the agreement. Any wage complements, accounting on average for approximately 35 percent of the remaining wage, are subsequently added to the base wage. As such, policies in the lines of comparable worth, equal employment and promotion opportunities, affirmative action, as well as equal pay legislation can potentially reduce female-male wage differentials.

\section{Data}

We use data from the 1995 and 2002 Spanish Wage Structure Surveys (EES 95 and EES 02). These datasets survey random samples of workers in establishments with 10 or more employees within the manufacturing, construction and service industries. ${ }^{4}$ The sampling takes place in two stages. In the first stage, establishments are randomly selected from the Social Security General Register of Payments records, which are stratified by region and establishment

\footnotetext{
${ }^{4}$ Workers in establishments with 10 or more employees accounted for approximately 70.75 percent of the working
} 
size. In a second stage, a sample of workers is randomly selected from each establishment. An average of 5 workers are interviewed in establishments with 10-20 employees, seven workers in establishments with 21-50 employees, twelve workers in establishments with 51-100 employees, twenty workers in establishments with 100-200 employees, and 25 workers in establishments with more than 200 employees. Overall, sample sizes are significantly larger than those provided by any other Spanish survey. ${ }^{5}$ Table 1 summarizes the main characteristics of both samples. The EES-95 samples a total of 125,865 full-time workers $(99,106$ males and 26,759 females) from 14,347 different establishments, whereas the EES-2002 samples 169,520 full-time workers (117,161 men and 52,359 women) from 21,621 establishments. ${ }^{6}$

The EES surveys collect detailed information on workers' wages -including their base wage and wage complements, as well as on workers' demographic (such as age and educational attainment) and job characteristics (including industry, occupation, contract type, type of collective bargaining, the establishment's market orientation, establishment size, and region). Table 1 shows descriptive statistics for both samples of full-time employees. ${ }^{7}$ The wage variable is the hourly wage in euros. The figures for 1995 reveal that the full-time female-male wage ratio was 75 percent, thus similar to the unrestricted female-male wage ratio of 74 found by De la Rica and Ugidos (1995) using Spanish data from the 1991 ECBC survey. Additionally, men were, on average, older and less educated than full-time female workers. Regarding job characteristics, female workers were more likely to hold a fixed-term contract, less likely to be

population in Spain in both 1995 and 2002.

${ }^{5}$ Unfortunately, surveys with individual level information on wages are scarce in Spain. In fact, information on individual wages for the nineties can only be found in the ECBC-1991 (see De la Rica and Ugidos (1995)) and in the European Panel of Households (1994-2001). However, their samples are significantly smaller and both are household surveys, thereby lacking the needed matched employer-employee information for this analysis.

${ }^{6}$ Focusing on full-time workers ensures the comparability of our findings to those from other studies in the literature (e.g. Groshen 1991, Bayard et al. 2003, Gupta and Rothstein 2005).

${ }^{7}$ The percentage of part-timers in our sample is about 5 percent, which is a little bit lower than the average part-time rate in Spain, which is about 8. 
covered by firm collective agreements (as opposed to collective agreements negotiated at the industry level), and more likely to be employed in larger firms relative to their male counterparts. By 2002, the full-time female-male wage ratio had increased to 78 percent, possibly favoured by equalizing factors such as: (1) the decline in the age difference between men and women to less than two years; (2) the significant increase in the percentage of women with a college degree (from 11 percent in 1995 to 26 percent seven years later); and (3) the reduction in gender differences when it comes to the type of work contract held.

How segregated were Spanish workers as of 1995 and 2002? The answer to this question depends on the level at which segregation is measured. We use four different levels of employment segregation: industry, occupation, establishment, and occupation-establishment, which we will also refer to as the job cell level. There are 12 industries categories in our data and a total of 56 occupations when measured at the finest level, that is, the two-digit level of the ISCO- 88 classification. ${ }^{8}$ Since the purpose of the analysis is to gain a better understanding of the size and composition of the gender wage gap at the job cell level, we are interested in using the narrowest occupational classification possible. However, because our data consist of a sample of workers at each establishment, some job cells are quite small. Therefore, we also carry out the analysis using a broader occupational classification, which results in just 7 occupational categories and bigger job cells, allowing us to assess the robustness of our findings to the use of alternative job cell sizes.

Tables 2A and 2B display the distribution of our sample by job cell size depending on whether we use the narrowest or the broader occupational classification, respectively. According to Table $2 \mathrm{~A}$, more than 20 percent of our job cells contain only one individual and only 10

\footnotetext{
${ }^{8}$ While there are more than 89 occupations at the two-digit level in the ISCO88 classification, fifty-six is the number of occupations that results once we exclude fisheries and focus on salaried workers.
} 
percent of the job cells have more than 10 workers when we employ the narrowest occupational classification possible. Given that the purpose of our analysis is to examine gender wage gaps within job cells, the lower panel of Table 2A also displays the sample distribution by job cell size when we restrict our attention to gender integrated job cells. Gender integrated job cells account for 24 to 34 percent of our original samples, already hinting on the extent of gender segregation. In contrast, when we use a broader occupational classification in Table 2B, only 10 percent of the job cells have 1 worker and an average of 25 percent of our job cells have more than 10 employees. Even as we restrict our sample to gender integrated job cells at the bottom of Table 2B, we still retain between 38 percent and 48 percent of our original sample versus 24 to 34 percent when using the narrowest occupational classification possible. Thus, we will focus our discussion on the results when using the broader occupational classification and display the findings from our analysis when we use the narrowest occupational classification possible in the Appendix. Additionally, some of the analysis is carried out using all job cells as well as using exclusively gender integrated job cells as a robustness check.

The figures in Table 3 and Table A in the Appendix provide a preliminary assessment of the extent gender segregation in Spain as of 1995 and 2002 using the broader and the narrowest occupational classifications, correspondingly. One of the most notable findings is the fact that segregation progressively rises as we move from the industry, to the occupation, to the establishment and, finally, to the job cell level. For instance, according to the figures in Table 3, the average woman worked in an industry that was 5 percentage points more female than the industry employing the average male worker as of 1995 . This percentage goes up to 11 and 35 percentage points as we compare the occupations and establishments, respectively, where the average female and male employee worked in. At any rate, segregation was the largest at the job 
cell level. In particular, as of 1995, the average female employee worked in a job that was 71 percent female as opposed to 8 percent female in the case of an average male employee. Over the seven year period under consideration, segregation increased at the industry, occupation, and establishment levels despite the greater percentage of females employed in the industries, occupations, and establishments of average male workers. That is, the increase in gender segregation was due to the even faster growing concentration of women in primarily female industries, occupations and establishments. Only segregation at the job cell level actually diminished between 1995 and 2002. The figures in Table A in the Appendix tell a similar story; the main difference with respect to the findings from Table 3 being the greater segregation at the occupation and job cell levels due to the narrower occupational classification being used.

\section{Methodology}

We start by first estimating log wage regressions where the wage gap between men and women can be explained as a function of individual human capital, job characteristics, and female segregation into lower-paying industries, occupations, establishments, and occupations within establishments as captured by the proportion of women employed in each of these structures as follows:

$$
w_{\text {PIOEJ }}=\alpha+\beta F_{P}+I \gamma_{I}+O \gamma_{O}+E \gamma_{E}+J \gamma_{J}+X_{P} \delta+Z_{E} \phi+\varepsilon_{P I O E J}
$$

where $w$ is the log hourly wage; $F$ is a dichotomous variable equal to 1 if the individual $P$ is female; $I, O, E$, and $J$ are measures of the proportion of female workers at the industry, occupation, establishment or occupation-establishment (i.e. job cell) levels; $X$ is a vector of human capital characteristics (i.e., age and education); and $Z$ is a vector of work related characteristics that vary at the establishment level, such as establishment size, market orientation (i.e. whether the establishment's product is marketed at a local, national or international level), 
type of collective bargaining (i.e. whether it is firm-level bargaining or industry bargaining), and regional location. A couple of facts are worth noting with regards to equation (1). First, equation (1) implicitly assumes that the returns to age and education do not differ by gender. We should, however, note that the estimated role of segregation on the gender wage gap does not significantly differ when we estimate separate log wage regressions by gender so as to allow for gender differences in the returns to age and education. Therefore, we retain equation (1) as our benchmark specification to allow for the comparability of our results to those from other studies in the literature that also impose this restriction. Second, to the extent that the proportions of women in each industry, occupation, establishment, and, in particular, job cell level are computed from a sample of workers in each establishment, there is room for measurement error. Thus, as Bayard et al. (2003), we re-estimate equation (1) using job cell dummies that capture job cell fixed effects in place of variables capturing the proportion of females at each level as follows:

$$
w_{P I O E J}=\alpha+\beta F_{P}+J \gamma_{J}+X_{P} \delta+\varepsilon_{\text {PIOEJ }}
$$

where $J$ now stands for job cell level fixed-effects.

While the above specification addresses any measurement errors in the proportion of females at each of the work levels at which segregation is being measured, other sources of measurement error remain, as is the case with individual ability and inner skills (Card and De la Rica 2005). Observable characteristics, such as age and education, only inaccurately account for the latter. Suppose that the true, yet unobserved by the econometrician, individual skills are defined by:

(3) $X_{P}^{*}=X_{P}+a_{P}$

where $X_{P}$ are the observed measures of skills (age and education) and $a_{P}$ is the unobservable 
component of individual skills. Note that unobserved worker skills may be correlated with other regressors in $X_{P}$, with establishment level characteristics in $Z_{E}$, or they may vary by gender $\left(F_{P}\right)$, leading to potential biases in the estimation of our coefficients. Suppose, for instance, that $a_{P}$ varies across workers, with:

(4) $E\left(a_{P} \mid X_{P}, \bar{X}_{C W}, Z_{E}, F_{P}\right)=X_{P} \varphi_{A}+\bar{X}_{C W} \mu_{A}+Z_{E} v_{A}+F_{P} \theta_{A}$

where $\bar{X}_{C W}$ stands for co-workers' average individual characteristics. If measurement error in the proportion of females appears negligible, as it would be the case when the results from the estimation of equation (1) and equation (2) are virtually the same, we could mitigate the measurement error in workers' skills by estimating the wage equation that results from substituting equation (4) into equation (1) as follows: ${ }^{9}$

(5) $w_{\text {PIOEJ }}=\alpha+F_{P}\left(\beta+\theta_{A}\right)+I \gamma_{I}+O \gamma_{O}+E \gamma_{E}+J \gamma_{J}+X_{P}\left(\delta+\varphi_{A}\right)+$ $+Z_{E}\left(\phi+v_{A}\right)+\bar{X}_{C W} \mu_{A}+a_{P}^{\prime}+\varepsilon_{P I O E J}$

where $a_{P}^{\prime}$ represents the unobserved skill component orthogonal to the observed data. According to equation (5), when the unobserved skill component is correlated with either gender or any of the regressors included in $X_{P}$ or $Z_{E}$, the estimated coefficients $\beta, \delta$, and $\phi$ in equation (1) are biased by a factor of $\theta_{A}, \varphi_{A}$, and $v_{A}$ respectively. In those instances, information on co-workers' characteristics may help reduce this bias. Why? Because workers with less human capital working side by side highly educated individuals are likely to be highly skilled workers and vice versa. As such, including the average educational attainment of co-

\footnotetext{
${ }^{9}$ A similar approach is commonly used in the hierarchical models' literature, where the unobserved effect is allowed to depend on cluster-level covariates.
} 
workers can help mitigate the measurement error incurred when trying to control for unobserved individual skills through the use of observable characteristics, such as age and education. ${ }^{10}$

In what follows, we estimate equations (1), (2) and (5) as a means to check the robustness of our findings. Specifically, a comparison of the pooled OLS, fixed-effects, and augmented pooled OLS estimates allows us to gauge the significance of the unobserved individual effects as well as the extent of the female coefficient bias when different sources of measurement error are taken into account.

\section{Results}

\section{A) Pooled OLS Specification}

Table 4 displays the results from four different regression specifications using the broader occupational classification. ${ }^{11}$ The first specification shows the results when we include no controls in the wage regression. As noted by Bayard et al. (2003), this specification reports the raw wage gap and, as such, allows us to progressively assess how much of the gender wage gap can be attributed to female segregation into specific industries, occupations, establishments, and occupations within establishments. As a comparison to Groshen's (1991) results, Bayard et al.'s (2003) panel A in Table 4, and Gupta and Rothstein's (2005) specification (4) in Tables 3-4, specification (2) then includes variables indicative of the percent female in each of the work structures while excluding human capital and job characteristics. Subsequently, specifications (3) and (4) add basic human capital (i.e. age and education) and job characteristics (i.e. contract type, type of collective bargaining agreement, the establishment's market orientation,

\footnotetext{
${ }^{10}$ Card and De la Rica (2005) use a similar econometric method to examine the wage impact of firm level contracts in the presence of unobserved worker characteristics (such as skill) possibly correlated with job characteristics, such as the type of contract.

${ }^{11}$ The results using the narrowest occupational classification are shown in Table B in the Appendix. In general, using a narrower occupational classification allows us to attribute more of the gender wage gap to occupation as well as occupation-establishment segregation.
} 
establishment size, and region) to the wage regression as in Bayard et al.'s (2003) panel B in Table 4 and Gupta and Rothstein's (2005) specification (9) in Tables 3-4. Finally, in order to gauge the contribution of female segregation into lower-paying industries, occupations, establishments and occupations within establishments to the gender gap, we list the mean differences between the right-hand-side variables' values for women and men in the fifth column of Table 4. The figures indicate the presence of a higher concentration of women in industries, occupations, establishments, and, especially, occupation-establishment cells that are predominantly female. Finally, the last column of Table 4 shows the relative contribution of each variable in the most complete specification (i.e. no. 4) to the wage gap.

Table 4's top panel displays the results corresponding to 1995, whereas the bottom panel shows the results for 2002. Specification (1) shows that the mean difference in the log hourly wage between female and male workers is -0.26 in 1995 and -0.22 in 2002 . Therefore, the female-male wage gap decreased by approximately 13 percent during the seven year period. Including the measures of gender segregation in specification (2) cuts the female coefficient in half to approximately -0.17 in 1995 and -0.18 in 2002 . However, accounting for individual and job related characteristics does not change the female coefficient by much. Overall, even after controlling for basic individual and job characteristics as well as for gender segregation, female workers earned about 13 to 16 percent less than their male counterparts in 1995 and 2002 , respectively. Being female explains most of the gender wage gap, accounting for approximately 49 percent in 1995 and for up to 70 percent in 2002. Does gender segregation contribute to the gender gap? The answer is yes, gender segregation plays a crucial role in explaining femalemale wage differentials. And, if so, which type of gender segregation is most responsible for the existing gender wage differences? Female segregation into lower-paying establishments and 
occupations within establishments contributed the most to the gender wage gap after workers' sex in both 1995 and 2002. In fact, the female-male wage differential would have decreased by 31.45 percent $(13.07+18.38)$ in 1995 and by 47.06 percent $(19.29+27.77)$ in 2002 if men and women would have been more equally distributed across establishments and occupations within establishments. We now turn to evaluating the robustness of our results by considering more refined estimation procedures as explained in the methodology.

\section{B) Fixed-effects Specification}

As we discussed earlier, sampling error in the proportion of women at the establishment and, in particular, occupation-establishment level can be severe when not using the entire population. A way to address this shortcoming is by replacing the variables indicative of the percent of women in the industry, occupation, establishment, and occupation-establishment levels by a full set of job cell fixed-effects. We thus estimate two fixed-effects wage regressions. A simpler specification (i.e. column (1)) that excludes the individual and job characteristics and exclusively includes the job cell fixed effects as measures of gender segregation, and another specification (i.e. column (2)) that includes all of the above (i.e. equation (2)). The results from such estimations using the broader occupational classification are displayed in Table $5 .^{12}$ Overall, measurement error in the proportion female variables appears to have a negligible impact when it comes to measuring and decomposing the gender wage gap. As in Table 4, the female-male wage differential slightly decreases as we include measures of individual and job characteristics. Women still earned approximately 13 percent and 16 percent less than similar men within the same job cell as of 1995 and 2002, respectively. Additionally, similar percentages of the gender wage gap at the occupation-establishment level are left unexplained, 
with worker's sex explaining 52 percent in 1995 and up to 70 percent in 2002.

One of the criticisms that can be made to the findings in Table 5 is the fact that the female coefficient in the fixed-effects model is exclusively identified by the information provided by gender-integrated job cells, which account for 38 to 48 percent of our original samples (see Table 2B). We thus exclude non-gender integrated job cells from the analysis to gauge the extent to which our results are robust to the estimation with a lesser number of observations. Table 6 reveals that the gender wage gap and the contribution of workers' sex to the female-male wage difference remain practically unchanged when only gender-integrated cells are used.

\section{C) Addressing Measurement Errors in Workers' Human Capital}

The fixed-effects specification uncovered the same female-male wage differential as the pooled OLS specification using the proportion of females at the industry, occupation, establishment and occupation-establishment or job levels. As such, measurement error in the proportion of females employed at the various work levels appeared to have a negligible impact in the measuring and decomposing the gender wage gap. Therefore, we address other potential sources of bias in our estimates from equation (1) through the estimation of equation (5). This alternative specification continues to account for gender segregation using the proportion of females at each of the work levels under consideration while addressing any measurement errors in workers' human capital by controlling for co-workers' characteristics. These co-workers' characteristics include the average age, average educational attainment, and average proportions of temporary contracts, workers under 30, and workers over 50 in the job cell.

Estimation results for equation (5) are displayed in Table 7. Overall, the figures reveal

\footnotetext{
${ }^{12}$ The results using the narrowest occupational classification are shown in Table $\mathrm{C}$ in the Appendix. As with the
} 
similar findings to those uncovered in Tables 4 through 6 . Females continue to earn approximately 13 percent and 16 percent less than similar male counterparts as of 1995 and 2002, respectively. Likewise, workers' sex accounts for 52 percent and for 72 percent of the gender wage gap in 1995 and 2002, correspondingly. Perhaps the major difference with respect to previous findings is the fact that the returns to education, a proxy for workers' human capital, significantly decrease as we account for co-workers' average characteristics; thus hinting on the value of including these additional controls. ${ }^{13}$ Table E in the Appendix displays the results when using the narrowest occupational classification possible. The finer occupational categorization underscores the importance of segregation at the establishment-occupation level in explaining the gender wage gap and, as in Tables B through D, reduces the role played by workers' sex in explaining male-female wage differentials to 39 percent in 1995 and to 47 percent in 2002.

\section{Summary and Policy Implications}

This paper presents new evidence of the role of gender segregation at the industry, occupation, establishment, and occupation-establishment or job levels in explaining gender wage differentials of full-time salaried workers in Spain during 1995 and 2002. The literature on the impact of different levels of gender segregation on the female-male wage gap has focused on the U.S. and Northern European countries, such as Denmark, Norway, and Sweden. Yet, Spain displays very distinct labor market features characteristic of Southern European nations, such as a traditionally high unemployment rate, a low female labor force participation rate, and a high effective unionization rate. ${ }^{14}$ As noted earlier in the paper, these differences may not be trivial

\footnotetext{
pooled OLS results, using a narrower occupational classification allows us to explain more of the gender wage gap. ${ }^{13}$ Specifically, the returns to a secondary education change from 0.15 to 0.08 in 1995 and from 0.12 to 0.06 in 2002 . Similarly, the returns to a university degree shift from 0.59 to 0.18 in 1995 and from 0.64 to 0.10 in 2002 . These results are not reported due to space limitations, but they are available from the authors upon request.

${ }^{14}$ Effective unionization rates refer to the percentage of workers covered by collective bargaining independently of whether they are union members.
} 
when explaining gender occupational segregation, which also differs substantially across countries (e.g. Blau and Kahn 2001, Dolado et al. 2004).

Using data from the Spanish Wage Structure Surveys, we find that the full-time femalemale wage ratio was 75 percent in 1995 and it increased to 78 percent by the year 2002 . These gender differentials are smaller than the ones found by Bayard et al. (2003) for the U.S. and by Gupta and Rothstein (2005) for Denmark, yet significantly larger than the wage gap previously documented for Sweden by Meyersson Milgrom et al. (2001). ${ }^{15}$ As such, they emphasize the importance of country level studies when examining gender wage gaps and their determinants. Additionally, we find evidence of the overall stagnation in the gender wage gap over the seven year period (e.g. Altonji and Blank 1999, Gosling and Lemieux 2001).

When measuring female segregation into lower-paying occupations and jobs, we resort to two different occupational classifications: a broad classification that allows for larger job cells in the regression analysis and a two-digit level classification that captures female segregation into lower-paying occupations and jobs better. Regardless of the occupational classification used, we find that segregation is the largest at the occupation-establishment level, with the average woman working in a job cell that was 71 percent to 79 percent female and their male counterparts working in a job cell that was only 6 percent to 12 percent female as of 1995 and 2002, respectively. Similar findings have been reported for Denmark (Gupta and Rothstein 2005). Yet, over the seven year period under examination, segregation -as measured by the percentage point difference in femaleness- declined at the job cell level, whereas it increased at the industry, occupation, and establishment levels.

\footnotetext{
${ }^{15}$ Bayard et al. (2003) document a gender differential in log hourly wages of 0.38 for the U.S. as of 1990. Gupta and Rothstein (2005) find a gender wage gap for Denmark of 0.386 in 1983 and of 0.341 in 1995 . Finally, other studies, such as Meyersson Milgrom et al. (2001), document small gender wage gaps in the order of 5 percent during the 1970-1990 period in Sweden.
} 
We estimate various log hourly wage regressions specifications using: (1) controls for the proportion of females in the industry, occupation, establishment, and occupation-establishment levels; (2) occupation-establishment level fixed-effects; and (3) augmented pooled OLS regressions including co-worker average characteristics to address measurement errors in workers' human capital. Our results are quite robust to the econometric specification being used, with the major differences emerging from the type of occupational classification being used in the analysis. Specifically, the use of a narrower occupational classification helps explain more of the gender wage gap. However, while we display the results using the two occupational classifications, we focus our discussion on the results that surface from using a broader occupational classification since the latter ensures larger job cell sizes. We find three key results robust across a variety of regression specifications. First is the fact that, even after controlling for basic individual and job characteristics, as well as for gender segregation, female workers still earned about 13 to 16 percent less than their male counterparts in 1995 and 2002, respectively. A second finding worth noting is that workers' sex explained anywhere between 49 percent and 52 percent of the gender wage gap in 1995, and between 67 percent and 72 percent of the female-male wage differential as of 2002 depending on the methodology being used. Finally, segregation at the job cell and occupational levels were the most important types of segregation in explaining the gender wage gap, being responsible for 25 percent to 31 percent of the gender wage gap as of 1995 and for anywhere between 47 percent and 51 percent of the gender wage differential in 2002.

In sum, over the course of seven years, the raw gender wage gap decreased; yet, after accounting for workers' human capital and female segregation into lower-paying industries, occupations, establishments and job cells, women still earned about 13 percent and 16 percent 
than their male counterparts as of 1995 and 2002, respectively. As Groshen (1991) emphasized for the U.S., we find that the contribution of workers' sex to the Spanish female-male wage differential not only was the largest, but it further increased over the time period under consideration. Consequently, equal pay legislation could help reduce the significant gender wage gap within narrowly defined job cells. However, as Meyersson Milgrom et al. (2001), Bayard et al. (2003), and Gupta and Rothstein (2005), we also find that female segregation into lower-paying industries, establishments and, in particular, job cells, followed workers' sex in order of magnitude when explaining the persistent gender wage gap. In fact, these types of segregation explained more of the female-male wage differential in 2002 than they did seven years earlier. Therefore, the importance of combining equal pay legislation with policies in the lines of comparable worth, equal employment and promotion opportunities, and affirmative action when targeting persistent gender wage gaps. 


\section{References}

Abowd, J. and F. Kramarz. (1999). "The analysis of labor markets using matched employeremployee data" Handbook of Labor Economics, vol. 3B (chapter 40), ed. Ashenfelter and Card, Elsevier Science.

Altonji, J. and R. Blank. (1999). "Race and Gender in the Labor Market" Handbook of Labor Economics, vol. 3C (chapter 48), ed. Ashenfelter and Card, Elsevier Science.

Bayard, K., J. Hellerstein, D. Neumark and K. Troske. (2003). "New evidence on sex segregation and sex differences in wages from matched employee-employer data" Journal of Labor Economics, 21(4): 887-923.

Card, D. and S. De la Rica. (2005). "The Effect of Establishment-Level Contracts on the Structure of Wages: Evidence from Matched Employer-Employee Data” IZA DP 1421.

Carrington, W. and K. Troske. (1998). "On measuring segregation in samples with small units" Journal of Business and Economic Statistics, vol. 15(4): 402-09.

De la Rica, S. and A. Ugidos. (1995). “¿Son las diferencias salariales en capital humano determinantes de las diferencias salariales observadas entre hombres y mujeres?" Investigaciones Económicas, vol. 19: 395-414.

Dolado, J. F. Felgueroso and J.F. Jimeno. (2004). "Where Do Women Work?: Analysis Patterns of Occupational Segregation by Gender" Annales d'Economie et de Statistique, Special Issue July-Dec. 2003, 0(71-72): 293-315.

Gosling, A. and T. Lemieux. (2001). "Labour market reforms and changes in wage inequality in the United Kingdom and the United States" NBER Working Paper N 8413.

Groshen, E. (1991). "The Structure of the Female/Male Wage differential: Is it who you are, what you do, or where you work?" The Journal of Human Resources, 26(3): 457-72.

Johnson, G. and G. Solon. (1986). "Estimates of the Direct Effects of Comparable Worth Policy" American Economic Review, 76 (5): 1117-25.

MacPherson, D. and B. Hirsch. (1995). "Wages and Gender Composition: Why do womens's Jobs Pay less?” Journal of Labor Economics, 13(3): 426-71.

Meyersson Milgrom, E., T. Petersen and V. Snartland. (2001). "Equal Pay for equal Work? Evidence from Sweden and a Comparison with Norway and the US" Scandinavian Journal of Economics, 103 (4): 559-583. 
Table 1

Descriptive Statistics

\begin{tabular}{|c|c|c|c|c|}
\hline \multirow{2}{*}{ Variables } & \multicolumn{2}{|c|}{ Men } & \multicolumn{2}{|c|}{ Women } \\
\hline & Mean & S.D. & Mean & S.D. \\
\hline & \multicolumn{4}{|c|}{ EES-1995 } \\
\hline Log hourly Wage & 1.744 & 0.49 & 1.486 & 0.43 \\
\hline Age & 39.79 & 10.92 & 34.73 & 9.70 \\
\hline$\%$ Primary or less & 0.37 & 0.34 & 0.36 & 0.35 \\
\hline$\%$ Secondary & 0.53 & 0.49 & 0.64 & 0.48 \\
\hline$\%$ University & 0.10 & 0.30 & 0.11 & 0.31 \\
\hline$\%$ Temporary Contracts & 0.24 & 0.43 & 0.29 & 0.45 \\
\hline$\%$ Firm col. bargaining & 0.25 & 0.43 & 0.18 & 0.38 \\
\hline$\%$ firm size $1(10-19)$ & 0.20 & 0.40 & 0.17 & 0.38 \\
\hline$\%$ firm size 2 (20-49) & 0.26 & 0.44 & 0.24 & 0.42 \\
\hline$\%$ firm size $3(50-99)$ & 0.17 & 0.37 & 0.17 & 0.38 \\
\hline$\%$ firm size $4(100-199)$ & 0.15 & 0.35 & 0.17 & 0.37 \\
\hline$\%$ firm size 5 (>199) & 0.22 & 0.41 & 0.25 & 0.43 \\
\hline \multirow[t]{2}{*}{ Observations } & \multicolumn{2}{|c|}{99106} & \multicolumn{2}{|c|}{26759} \\
\hline & \multicolumn{4}{|c|}{ EES-2002 } \\
\hline Log hourly Wage & 2.173 & 0.55 & 1.949 & 0.52 \\
\hline Age & 38.62 & 10.92 & 36.10 & 10.0 \\
\hline$\%$ Primary or less & 0.29 & 0.40 & 0.20 & 0.46 \\
\hline$\%$ Secondary & 0.56 & 0.49 & 0.54 & 0.50 \\
\hline$\%$ University & 0.15 & 0.36 & 0.26 & 0.44 \\
\hline$\%$ Temporary Contracts & 0.23 & 0.42 & 0.24 & 0.43 \\
\hline$\%$ Firm col. bargaining & 0.18 & 0.39 & 0.13 & 0.33 \\
\hline$\%$ firm size $1(10-49)$ & 0.39 & 0.49 & 0.34 & 0.47 \\
\hline$\%$ firm size $2(20-199)$ & 0.31 & 0.46 & 0.28 & 0.45 \\
\hline$\%$ firm size $3(>199)$ & 0.29 & 0.46 & 0.37 & 0.48 \\
\hline Observations & \multicolumn{2}{|c|}{117161} & \multicolumn{2}{|c|}{52359} \\
\hline
\end{tabular}


Table 2A

Sample Distribution

(Finest Occupational Classification - 56 categories)

\begin{tabular}{|c|c|c|c|c|}
\hline \multirow{2}{*}{ Size of Job-Cell } & Frequency & $\begin{array}{l}\text { Cumulative } \\
\text { Distribution }\end{array}$ & Frequency & $\begin{array}{l}\text { Cumulative } \\
\text { Distribution }\end{array}$ \\
\hline & \multicolumn{2}{|c|}{ EES-1995 } & \multicolumn{2}{|c|}{$E E S-2002$} \\
\hline 1 worker & 30,778 & 24.45 & 38,606 & 22.77 \\
\hline 2 workers & 20,190 & 40.49 & 25,232 & 37.66 \\
\hline 3 workers & 16,245 & 53.40 & 20,151 & 49.55 \\
\hline 4 workers & 13,772 & 64.34 & 18,300 & 60.34 \\
\hline 5 workers & 10,870 & 72.98 & 14,590 & 68.95 \\
\hline 6 workers & 7,044 & 78.58 & 10,440 & 75.11 \\
\hline 7 workers & 5,418 & 82.88 & 8,036 & 79.85 \\
\hline 8 workers & 3,472 & 85.64 & 6,016 & 83.39 \\
\hline 9 workers & 3,069 & 88.08 & 5,355 & 86.55 \\
\hline 10 workers & 2,490 & 90.06 & 3,660 & 88.71 \\
\hline 11-35 workers & 3,441 & 100 & 19,134 & 100 \\
\hline \multirow[t]{2}{*}{ Total size } & \multicolumn{2}{|c|}{125,865} & \multicolumn{2}{|c|}{169,520} \\
\hline & \multicolumn{2}{|c|}{ Gender Integrated Cells in the EES-1995 } & \multicolumn{2}{|c|}{ Gender Integrated Cells in the EES-2002 } \\
\hline 2 workers & 3,072 & 10.37 & 5,666 & 9.91 \\
\hline 3 workers & 3,480 & 22.11 & 6,081 & 20.55 \\
\hline 4 workers & 3,748 & 34.76 & 7,072 & 32.92 \\
\hline 5 workers & 3,395 & 46.22 & 6,040 & 43.48 \\
\hline 6 workers & 2,598 & 54.99 & 4,980 & 52.19 \\
\hline 7 workers & 2,198 & 62.41 & 4,620 & 60.27 \\
\hline 8 workers & 1,576 & 67.73 & 3,536 & 66.46 \\
\hline 9 workers & 1,368 & 72.35 & 3,285 & 72.20 \\
\hline 10 workers & 1,200 & 76.40 & 2,250 & 76.14 \\
\hline $11-35$ workers & 6,993 & 100 & 11,652 & 100 \\
\hline Total size & \multicolumn{2}{|c|}{29,628} & \multicolumn{2}{|c|}{57,173} \\
\hline
\end{tabular}


Table 2B

Sample Distribution

(Broader Occupational Classification - 7 categories)

\begin{tabular}{|c|c|c|c|c|}
\hline \multirow{2}{*}{ Size of Job-Cell } & Frequency & $\begin{array}{l}\text { Cumulative } \\
\text { Distribution }\end{array}$ & Frequency & $\begin{array}{l}\text { Cumulative } \\
\text { Distribution }\end{array}$ \\
\hline & \multicolumn{2}{|c|}{ EES-1995 } & \multicolumn{2}{|c|}{$E E S-2002$} \\
\hline 1 worker & 16,914 & 13.44 & 21,325 & 12.58 \\
\hline 2 workers & 15,950 & 26.11 & 20,434 & 24.63 \\
\hline 3 workers & 15,888 & 38.73 & 19,383 & 36.07 \\
\hline 4 workers & 15,284 & 50.88 & 19,444 & 47.54 \\
\hline 5 workers & 13,310 & 61.45 & 16,780 & 57.44 \\
\hline 6 workers & 9,066 & 68.65 & 12,558 & 64.84 \\
\hline 7 workers & 6,916 & 74.15 & 9,821 & 70.64 \\
\hline 8 workers & 5,016 & 78.13 & 7,216 & 74.89 \\
\hline 9 workers & 3,933 & 81.26 & 6,525 & 78.74 \\
\hline 10 workers & 3,630 & 84.14 & 5,630 & 82.06 \\
\hline 11-35 workers & 19,962 & 100 & 26,462 & 100 \\
\hline \multirow[t]{2}{*}{ Total size } & \multicolumn{2}{|c|}{125,865} & \multicolumn{2}{|c|}{169,520} \\
\hline & \multicolumn{2}{|c|}{ Gender Integrated Cells in the EES-1995 } & \multicolumn{2}{|c|}{ Gender Integrated Cells in the EES-2002 } \\
\hline 2 workers & 3,160 & 7.86 & 5676 & 7.62 \\
\hline 3 workers & 4,008 & 17.82 & 6711 & 16.63 \\
\hline 4 workers & 4,612 & 29.28 & 7964 & 27.33 \\
\hline 5 workers & 4,355 & 40.11 & 7550 & 37.46 \\
\hline 6 workers & 3,588 & 49.03 & 6228 & 45.83 \\
\hline 7 workers & 3,045 & 56.60 & 5614 & 53.36 \\
\hline 8 workers & 2,456 & 62.70 & 4400 & 59.27 \\
\hline 9 workers & 1,971 & 67.60 & 4248 & 64.98 \\
\hline 10 workers & 1,900 & 72.33 & 3660 & 69.89 \\
\hline $11-35$ workers & 9,063 & 100 & 22424 & 100 \\
\hline Total size & \multicolumn{2}{|c|}{40,227} & \multicolumn{2}{|c|}{74,475} \\
\hline
\end{tabular}


Table 3

Gender Segregation at Various Work Levels

(Broader Occupational Classification - 7 categories)

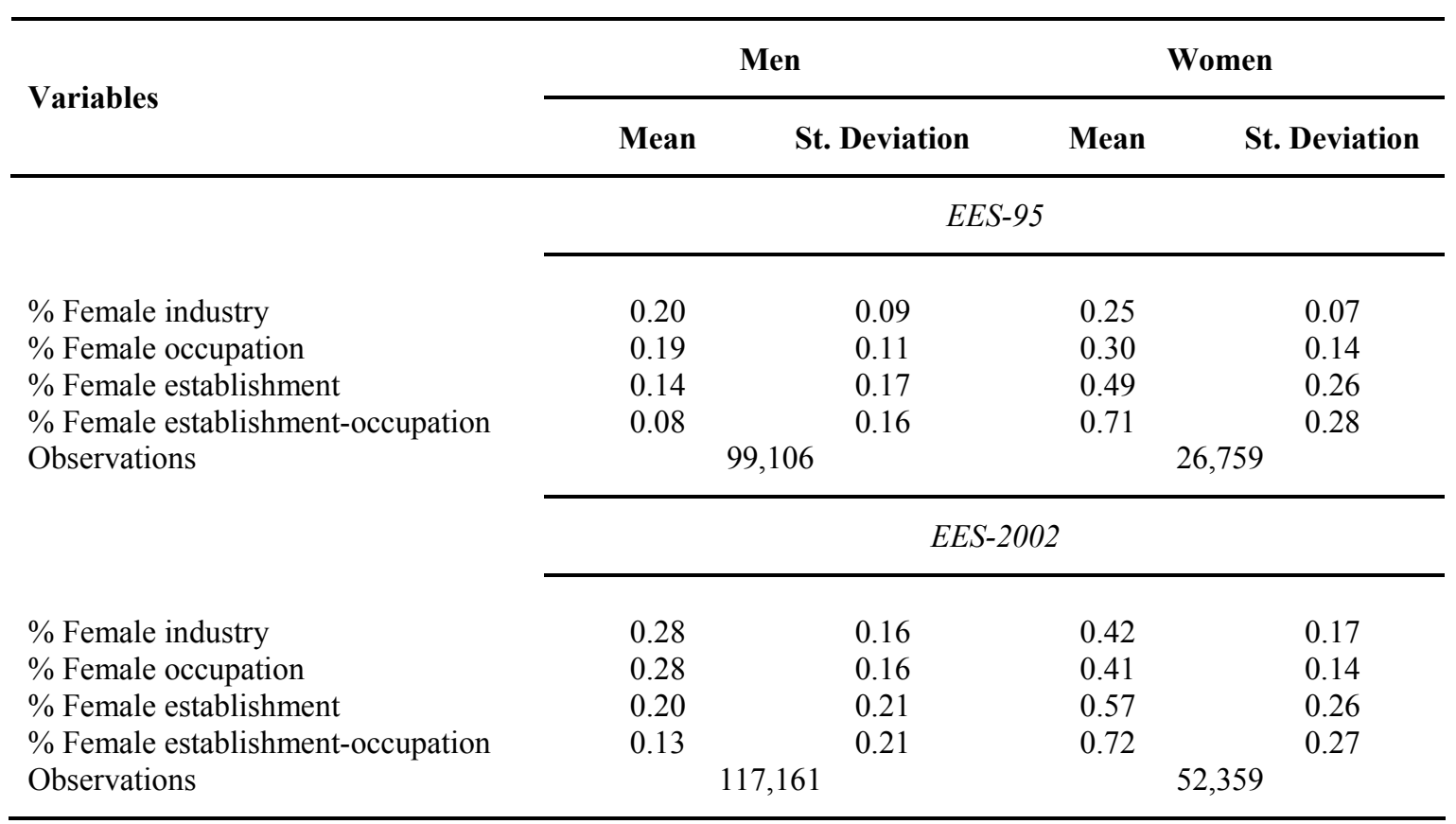


Table 4

Gender Segregation and Its Contribution to the Male-Female Wage Gap

(Broader Occupational Classification - 7 categories)

(Dependent Variable: Log hourly Wages)

\begin{tabular}{|c|c|c|c|c|c|c|}
\hline Variables & (1) & (2) & (3) & (4) & $\begin{array}{c}\text { Mean } \\
\text { Diff. } \\
\text { Women- } \\
\text { Men } \\
\end{array}$ & $\begin{array}{c}\text { Relative } \\
\text { Contribution } \\
\text { to Gap } \\
\text { in (4) } \\
\end{array}$ \\
\hline & \multicolumn{6}{|c|}{ EES-1995 } \\
\hline Female Dummy & $\begin{array}{l}-0.257 \\
(0.003)\end{array}$ & $\begin{array}{l}-0.169 \\
(0.003)\end{array}$ & $\begin{array}{l}-0.119 \\
(0.003)\end{array}$ & $\begin{array}{l}-0.125 \\
(0.003)\end{array}$ & 1 & 48.63 \\
\hline$\%$ Female industry (12 categories) & - & $\begin{array}{l}-0.144 \\
(0.050)\end{array}$ & $\begin{array}{l}-0.147 \\
(0.039)\end{array}$ & $\begin{array}{l}-0.203 \\
(0.033)\end{array}$ & 0.05 & 3.94 \\
\hline \% Female occupation (7 categ.) & - & $\begin{array}{l}-0.077 \\
(0.019)\end{array}$ & $\begin{array}{l}-0.039 \\
(0.016)\end{array}$ & $\begin{array}{l}-0.045 \\
(0.014)\end{array}$ & 0.11 & 1.92 \\
\hline$\%$ Female establishment & - & $\begin{array}{l}-0.070 \\
(0.017)\end{array}$ & $\begin{array}{l}-0.054 \\
(0.013)\end{array}$ & $\begin{array}{l}-0.096 \\
(0.011)\end{array}$ & 0.35 & 13.07 \\
\hline$\%$ Female job cell & - & $\begin{array}{l}-0.096 \\
(0.008)\end{array}$ & $\begin{array}{l}-0.066 \\
(0.007)\end{array}$ & $\begin{array}{l}-0.075 \\
(0.006)\end{array}$ & 0.63 & 18.38 \\
\hline $\begin{array}{l}\text { Observable skills } \\
\text { (age, education) }\end{array}$ & No & No & Yes & Yes & & \\
\hline $\begin{array}{l}\text { Job characteristics } \\
\text { (contract type, ...) }\end{array}$ & No & No & No & Yes & & \\
\hline R-squared & 0.046 & 0.05 & 0.34 & 0.47 & & \\
\hline \multirow[t]{2}{*}{ Observations } & \multicolumn{6}{|c|}{125865} \\
\hline & \multicolumn{6}{|c|}{ EES-2002 } \\
\hline Female Dummy & $\begin{array}{c}-0.224 \\
(0.003)\end{array}$ & $\begin{array}{l}-0.180 \\
(0.003)\end{array}$ & $\begin{array}{l}-0.160 \\
(0.003)\end{array}$ & $\begin{array}{l}-0.159 \\
(0.003)\end{array}$ & 1 & 70.01 \\
\hline $\begin{array}{l}\% \text { Female industry } \\
\text { (12 categories) }\end{array}$ & - & $\begin{array}{c}0.358 \\
(0.029)\end{array}$ & $\begin{array}{l}-0.043 \\
(0.021)\end{array}$ & $\begin{array}{l}-0.181 \\
(0.020)\end{array}$ & 0.14 & 9.80 \\
\hline $\begin{array}{l}\% \text { Female occupation } \\
\text { ( } 7 \text { categories) }\end{array}$ & - & $\begin{array}{c}0.424 \\
(0.019)\end{array}$ & $\begin{array}{c}0.178 \\
(0.014)\end{array}$ & $\begin{array}{c}0.128 \\
(0.013)\end{array}$ & 0.13 & -6.47 \\
\hline$\%$ Female establishment & - & $\begin{array}{l}-0.107 \\
(0.015)\end{array}$ & $\begin{array}{l}-0.113 \\
(0.011)\end{array}$ & $\begin{array}{l}-0.134 \\
(0.010)\end{array}$ & 0.37 & 19.29 \\
\hline $\begin{array}{l}\text { \% Female establishment- } \\
\text { occupation }\end{array}$ & - & $\begin{array}{l}-0.166 \\
(0.007)\end{array}$ & $\begin{array}{l}-0.126 \\
(0.006)\end{array}$ & $\begin{array}{l}-0.121 \\
(0.005)\end{array}$ & 0.59 & 27.77 \\
\hline $\begin{array}{l}\text { Observable skills } \\
\text { (age, education) }\end{array}$ & No & No & Yes & Yes & & \\
\hline $\begin{array}{l}\text { Job characteristics } \\
\text { (contract type, ...) }\end{array}$ & No & No & No & Yes & & \\
\hline R-squared & 0.035 & 0.035 & 0.360 & 0.475 & & \\
\hline Observations & \multicolumn{6}{|c|}{169520} \\
\hline
\end{tabular}

Notes: Job characteristics include the type of contract, market orientation of the establishment (e.g. international, national, local), establishment size (4 size dummies in EES-95 and 2 size dummies in EES-2002), type of collective agreement and 17 regional dummies. Standard errors are calculated allowing for clustering at the establishment level. The relative contribution to the gap is calculated as follows: $\{$ [coefficient of column (4)*Mean Diff. WomenMen]/raw wage gap\}. 
Table 5

Fixed-Effects Estimation of Log Wage Differentials by Gender (Broader Occupational Classification - 7 categories)

\begin{tabular}{lccc}
\hline Variables & $\mathbf{( 1 )}$ & $\mathbf{( 2 )}$ & $\begin{array}{c}\text { Relative } \\
\text { Contribution } \\
\text { to Gap in (2) }\end{array}$ \\
\hline & & $E E S-1995$ & \\
\cline { 2 - 4 } Female Dummy & -0.160 & -0.133 & 51.75 \\
Observable skills (age and & $(0.003)$ & $(0.002)$ & \\
education) plus type of contract & No & Yes & \\
R-squared & 0.046 & 0.335 & \\
Observations & & 125865 & \\
Groups & & 42023 & \\
& & $E E S-2002$ & \\
\cline { 2 - 4 } & & -0.156 & \\
Female & -0.181 & $(0.002)$ & \\
Observable skills (age and & $(0.002)$ & Yes & \\
education) plus type of contract & No & 0.255 & \\
R-squared & 0.035 & 169238 & \\
Observations & & 54017 & \\
Groups & & & \\
\hline
\end{tabular}


Table 6

Fixed-Effects Estimation of Log Wage Differentials by Gender Using Only Gender Integrated Job Cells (Broader Occupational Classification - 7 categories)

\begin{tabular}{lccc}
\hline Variables & $(\mathbf{1})$ & $\mathbf{( 2 )}$ & $\begin{array}{c}\text { Relative } \\
\text { Contribution } \\
\text { to the Gap } \\
\text { from (2) }\end{array}$ \\
\hline & & $E E S-1995$ & 50.2 \\
Female Dummy & -0.160 & -0.129 & $(0.002)$ \\
Observable skills (age and & $(0.003)$ & Yes & \\
education) plus type of contract & No & 0.357 & \\
R-squared & 0.066 & 40227 & \\
Observations & & 7484 & \\
Groups & & $E E S-2002$ & \\
& & -0.151 & $(0.002)$ \\
& & Yes & \\
Female & -0.181 & 0.283 & \\
Observable skills (age and & $(0.002)$ & 74,193 & \\
education) plus type of contract & No & 13330 & \\
R-squared & 0.035 & & \\
Observations & & & \\
Groups & & & \\
\hline
\end{tabular}


Table 7

Augmented OLS Estimation of Gender Segregation and Its Contribution to the Male-Female Wage Gap (Broader Occupational Classification - 7 categories)

\begin{tabular}{|c|c|c|c|}
\hline Variables & Coefficients & $\begin{array}{c}\text { Mean Diff. } \\
\text { Women-Men }\end{array}$ & $\begin{array}{c}\text { Relative } \\
\text { Contribution } \\
\text { to Gap in (4) } \\
\end{array}$ \\
\hline & \multicolumn{3}{|c|}{ EES-95 } \\
\hline Female Dummy & $\begin{array}{l}-0.135 \\
(0.003)\end{array}$ & 1 & 52.5 \\
\hline $\begin{array}{l}\% \text { Female industry } \\
\text { (12 categories) }\end{array}$ & $\begin{array}{l}-0.101 \\
(0.026)\end{array}$ & 0.13 & 5.10 \\
\hline $\begin{array}{l}\% \text { Female occupation } \\
\text { (56 categories) }\end{array}$ & $\begin{array}{c}0.003 \\
(0.016)\end{array}$ & 0.12 & -1.40 \\
\hline$\%$ Female establishment & $\begin{array}{l}-0.098 \\
(0.011)\end{array}$ & 0.38 & 14.49 \\
\hline$\%$ Female establishment-occupation & $\begin{array}{l}-0.048 \\
(0.007)\end{array}$ & 0.54 & 10.08 \\
\hline \multirow[t]{2}{*}{ Observations } & 0.513 & 125865 & \\
\hline & & EES-2002 & \\
\hline Female Dummy & $\begin{array}{l}-0.161 \\
(0.002)\end{array}$ & 1 & 71.87 \\
\hline $\begin{array}{l}\% \text { Female industry } \\
\text { (12 categories) }\end{array}$ & $\begin{array}{l}-0.195 \\
(0.017)\end{array}$ & 0.14 & 12.18 \\
\hline $\begin{array}{l}\% \text { Female occupation } \\
\text { ( } 7 \text { categories) }\end{array}$ & $\begin{array}{c}0.121 \\
(0.013)\end{array}$ & 0.13 & -7.02 \\
\hline$\%$ Female establishment & $\begin{array}{l}-0.138 \\
(0.010)\end{array}$ & 0.37 & 22.79 \\
\hline$\%$ Female establishment-occupation & $\begin{array}{l}-0.108 \\
(0.007)\end{array}$ & 0.59 & 28.44 \\
\hline $\begin{array}{l}\text { R-squared } \\
\text { Observations }\end{array}$ & 0.493 & 169,520 & \\
\hline
\end{tabular}

Notes: The regressions include age, age squared, education, type of contract, and other job characteristics such as the market orientation of the establishment, establishment size (4 size dummies in EES-95 and 2 size dummies in EES-2002), type of collective agreement, and 17 regional dummies. Additionally, the regressions include the average age, educational attainment and proportion of temporary contracts at the occupation-establishment or job cell level. Standard errors are calculated allowing for clustering at the establishment level. The relative contribution to the gap is calculated as follows: $\{$ [coefficient of column (4)*Mean Diff. Women-Men]/raw wage gap . 


\section{APPENDIX TABLES}

Table A

Gender Segregation at Various Work Levels (Finest Occupational Classification - 56 categories)

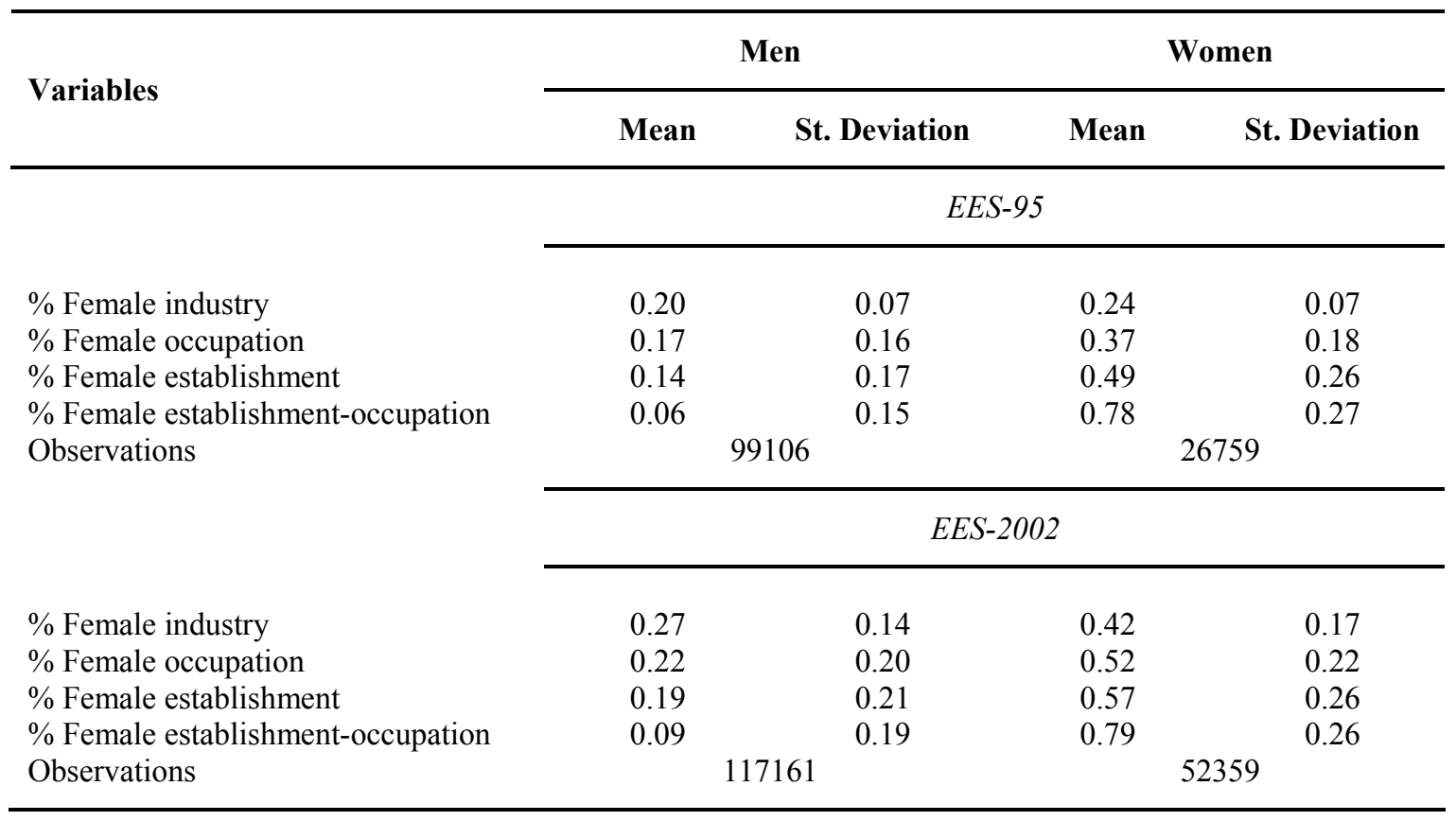


Table B

Gender Segregation and Its Contribution to the Male-Female Wage Gap

(Finest Occupational Classification - 56 categories)

(Dependent Variable: Log hourly Wages)

\begin{tabular}{|c|c|c|c|c|c|c|}
\hline Variables & (1) & (2) & (3) & (4) & $\begin{array}{c}\text { Mean Diff. } \\
\text { Women- } \\
\text { Men } \\
\end{array}$ & $\begin{array}{c}\text { Relative } \\
\text { Contribution } \\
\text { to Gap in (4) } \\
\end{array}$ \\
\hline & \multicolumn{6}{|c|}{ EES-1995 } \\
\hline Female Dummy & $\begin{array}{l}-0.257 \\
(0.03)\end{array}$ & $\begin{array}{l}-0.122 \\
(0.006)\end{array}$ & $\begin{array}{l}-0.094 \\
(0.005)\end{array}$ & $\begin{array}{l}-0.099 \\
(0.004)\end{array}$ & 1 & 38.5 \\
\hline $\begin{array}{l}\% \text { Female industry } \\
\text { (12 categories) }\end{array}$ & - & $\begin{array}{l}-0.082 \\
(0.020)\end{array}$ & $\begin{array}{l}-0.084 \\
(0.016)\end{array}$ & $\begin{array}{l}-0.120 \\
(0.014)\end{array}$ & 0.03 & 1.4 \\
\hline $\begin{array}{l}\% \text { Female occupation } \\
\text { (64 categories) }\end{array}$ & - & $\begin{array}{l}-0.146 \\
(0.008)\end{array}$ & $\begin{array}{l}-0.124 \\
(0.007)\end{array}$ & $\begin{array}{l}-0.159 \\
(0.009)\end{array}$ & 0.204 & 14.8 \\
\hline$\%$ Female establishment & - & $\begin{array}{l}-0.069 \\
(0.008)\end{array}$ & $\begin{array}{l}-0.057 \\
(0.006)\end{array}$ & $\begin{array}{l}-0.106 \\
(0.006)\end{array}$ & 0.52 & 21.45 \\
\hline $\begin{array}{l}\% \text { Female establishment- } \\
\text { occupation }\end{array}$ & - & $\begin{array}{l}-0.107 \\
(0.008)\end{array}$ & $\begin{array}{l}-0.06 \\
(0.007)\end{array}$ & $\begin{array}{l}-0.064 \\
(0.006)\end{array}$ & 0.728 & 18.13 \\
\hline $\begin{array}{l}\text { Observable skills } \\
\text { (age, education) }\end{array}$ & No & No & Yes & Yes & & \\
\hline $\begin{array}{l}\text { Job characteristics } \\
\text { (contract type, ...) }\end{array}$ & No & No & No & Yes & & \\
\hline R-squared & 0.046 & 0.05 & 0.34 & 0.47 & & \\
\hline \multirow[t]{2}{*}{ Observations } & & & & 125865 & & \\
\hline & \multicolumn{6}{|c|}{$E E S-2002$} \\
\hline Female Dummy & $\begin{array}{l}-0.224 \\
(0.003)\end{array}$ & $\begin{array}{l}-0.135 \\
(0.003)\end{array}$ & $\begin{array}{l}-0.121 \\
(0.003)\end{array}$ & $\begin{array}{l}-0.118 \\
(0.003)\end{array}$ & 1 & 52.7 \\
\hline $\begin{array}{l}\% \text { Female industry } \\
\text { (12 categories) }\end{array}$ & - & $\begin{array}{c}0.513 \\
(0.029)\end{array}$ & $\begin{array}{c}0.062 \\
(0.022)\end{array}$ & $\begin{array}{l}-0.084 \\
(0.021)\end{array}$ & 0.15 & 5.62 \\
\hline $\begin{array}{l}\text { \% Female occupation } \\
\text { (64 categories) }\end{array}$ & - & $\begin{array}{c}0.004 \\
(0.013)\end{array}$ & $\begin{array}{l}-0.084 \\
(0.010)\end{array}$ & $\begin{array}{l}-0.100 \\
(0.006)\end{array}$ & 0.30 & 13.39 \\
\hline$\%$ Female establishment & - & $\begin{array}{l}-0.124 \\
(0.014)\end{array}$ & $\begin{array}{l}-0.117 \\
(0.011)\end{array}$ & $\begin{array}{l}-0.097 \\
(0.009)\end{array}$ & 0.38 & 16.45 \\
\hline $\begin{array}{l}\% \text { Female establishment- } \\
\text { occupation }\end{array}$ & - & $\begin{array}{l}-0.155 \\
(0.006)\end{array}$ & $\begin{array}{l}-0.121 \\
(0.006)\end{array}$ & $\begin{array}{l}-0.135 \\
(0.010)\end{array}$ & 0.70 & 42.18 \\
\hline $\begin{array}{l}\text { Observable skills } \\
\text { (age, education) }\end{array}$ & No & No & Yes & Yes & & \\
\hline $\begin{array}{l}\text { Job characteristics } \\
\text { (contract type, ...) }\end{array}$ & No & No & No & Yes & & \\
\hline R-squared & 0.035 & 0.053 & 0.362 & 0.477 & & \\
\hline Observations & & & & 169520 & & \\
\hline
\end{tabular}

Notes: Job characteristics include the type of contract, market orientation of the establishment (e.g. international, national, local), establishment size (4 size dummies in EES-95 and 2 size dummies in EES2002), type of collective agreement and 17 regional dummies. Standard errors are calculated allowing for clustering at the establishment level. The relative contribution to the gap is calculated as follows: $\{[$ coefficient of column (4)*Mean Diff. Women-Men]/raw wage gap $\}$. 
Table C

Fixed-Effects Estimation of Log Wage Differentials by Gender

(Finest Occupational Classification - 56 categories)

\begin{tabular}{|c|c|c|c|}
\hline Variables & (1) & (2) & $\begin{array}{c}\text { Relative } \\
\text { Contribution } \\
\text { to Gap in (2) } \\
\end{array}$ \\
\hline & \multicolumn{3}{|c|}{ EES-1995 } \\
\hline Female Dummy & $\begin{array}{l}-0.122 \\
(0.003)\end{array}$ & $\begin{array}{l}-0.105 \\
(0.002)\end{array}$ & 40.8 \\
\hline $\begin{array}{l}\text { Observable skills (age and } \\
\text { education) plus type of contract }\end{array}$ & No & Yes & \\
\hline R-squared & 0.046 & 0.325 & \\
\hline \multirow[t]{2}{*}{$\begin{array}{l}\text { Observations } \\
\text { Groups }\end{array}$} & \multicolumn{3}{|c|}{$\begin{array}{c}125865 \\
55801\end{array}$} \\
\hline & \multicolumn{3}{|c|}{ EES-2002 } \\
\hline Female & $\begin{array}{l}-0.135 \\
(0.002)\end{array}$ & $\begin{array}{l}-0.117 \\
(0.002)\end{array}$ & 52.2 \\
\hline $\begin{array}{l}\text { Observable skills (age and } \\
\text { education) plus type of contract }\end{array}$ & No & Yes & \\
\hline R-squared & 0.035 & 0.243 & \\
\hline $\begin{array}{l}\text { Observations } \\
\text { Groups }\end{array}$ & & $\begin{array}{c}169520 \\
71382\end{array}$ & \\
\hline
\end{tabular}


Table D

Fixed-Effects Estimation of Log Wage Differentials by Gender Using Only Gender Integrated Job Cells (Finest Occupational Classification - 56 categories)

\begin{tabular}{|c|c|c|c|}
\hline Variables & (1) & (2) & $\begin{array}{c}\text { Relative } \\
\text { Contribution } \\
\text { to the Gap } \\
\text { from (2) } \\
\end{array}$ \\
\hline & \multicolumn{3}{|c|}{ EES-1995 } \\
\hline Female Dummy & $\begin{array}{l}-0.122 \\
(0.003)\end{array}$ & $\begin{array}{l}-0.102 \\
(0.003)\end{array}$ & 39.6 \\
\hline $\begin{array}{l}\text { Observable skills (age and } \\
\text { education) plus type of contract }\end{array}$ & No & Yes & \\
\hline R-squared & 0.048 & 0.325 & \\
\hline \multirow[t]{2}{*}{$\begin{array}{l}\text { Observations } \\
\text { Groups }\end{array}$} & \multicolumn{3}{|c|}{$\begin{array}{c}29628 \\
6037\end{array}$} \\
\hline & \multicolumn{3}{|c|}{ EES-2002 } \\
\hline Female & $\begin{array}{l}-0.135 \\
(0.002)\end{array}$ & $\begin{array}{l}-0.113 \\
(0.002)\end{array}$ & 50.4 \\
\hline $\begin{array}{l}\text { Observable skills (age and } \\
\text { education) plus type of contract }\end{array}$ & No & Yes & \\
\hline R-squared & 0.035 & 0.248 & \\
\hline $\begin{array}{l}\text { Observations } \\
\text { Groups }\end{array}$ & & $\begin{array}{l}57173 \\
11303\end{array}$ & \\
\hline
\end{tabular}


Table E

Augmented OLS Estimation of Gender Segregation and Its Contribution to the Male-Female Wage Gap (Finest Occupational Classification - 56 categories)

\begin{tabular}{|c|c|c|c|}
\hline Variables & Coefficients & $\begin{array}{c}\text { Mean Diff. } \\
\text { Women-Men }\end{array}$ & $\begin{array}{c}\text { Relative } \\
\text { Contribution } \\
\text { to Gap in (4) }\end{array}$ \\
\hline & \multicolumn{3}{|c|}{ EES-95 } \\
\hline Female Dummy & $\begin{array}{l}-0.106 \\
(0.003)\end{array}$ & 1 & 38.9 \\
\hline $\begin{array}{l}\% \text { Female industry } \\
\text { (12 categories) }\end{array}$ & $\begin{array}{l}-0.108 \\
(0.03)\end{array}$ & 0.03 & 3.36 \\
\hline $\begin{array}{l}\% \text { Female occupation } \\
\text { (56 categories) }\end{array}$ & $\begin{array}{l}-0.124 \\
(0.015)\end{array}$ & 0.18 & 8.68 \\
\hline$\%$ Female establishment & $\begin{array}{l}-0.078 \\
(0.014)\end{array}$ & 0.40 & 12.14 \\
\hline$\%$ Female establishment-occupation & $\begin{array}{l}-0.076 \\
(0.011)\end{array}$ & 0.64 & 18.92 \\
\hline \multirow[t]{2}{*}{ Observations } & 0.513 & 95,087 & \\
\hline & & EES-2002 & \\
\hline Female Dummy & $\begin{array}{c}-0.12 \\
(0.003)\end{array}$ & 1 & 46.69 \\
\hline $\begin{array}{l}\% \text { Female industry } \\
\text { (12 categories) }\end{array}$ & $\begin{array}{l}-0.18 \\
(0.02)\end{array}$ & 0.13 & 9.1 \\
\hline $\begin{array}{l}\% \text { Female occupation } \\
\text { (56 categories) }\end{array}$ & $\begin{array}{l}-0.075 \\
(0.013)\end{array}$ & 0.27 & 3.54 \\
\hline$\%$ Female establishment & $\begin{array}{l}-0.095 \\
(0.013)\end{array}$ & 0.41 & 14.35 \\
\hline$\%$ Female establishment-occupation & $\begin{array}{c}-0.17 \\
(0.010)\end{array}$ & 0.60 & 39.68 \\
\hline R-squared & 0.53 & & \\
\hline Observations & & 130,914 & \\
\hline
\end{tabular}

Notes: The regressions include age, age squared, education, type of contract, and other job characteristics such as the market orientation of the establishment, establishment size (4 size dummies in EES-95 and 2 size dummies in EES-2002), type of collective agreement, and 17 regional dummies. Additionally, the regressions include the average age, educational attainment and proportion of temporary contracts at the occupation-establishment or job cell level. Standard errors are calculated allowing for clustering at the establishment level. The relative contribution to the gap is calculated as follows: $\{$ [coefficient of column (4)*Mean Diff. Women-Men]/raw wage gap . 